\title{
Cigarette filter ventilation is a defective design because of misleading taste, bigger puffs, and blocked vents
}

\author{
L T Kozlowski, R J O'Connor
}

Tobacco Control 2002; 11 (Suppl I):i40-i50

See end of article for authors' affiliations

Correspondence to: Lynn T Kozlowski, PhD, Department of

Biobehavioral Health, The

Pennsylvania State

University, 315 East

Henderson Building

University Park, PA 16802,

USA; Itk1@psu.edu
Objective: To review tobacco industry documents on filter ventilation in light of published studies and to explore the role of filter ventilation in the design of cigarettes that deliver higher smoke yields to smokers than would be expected from standard machine smoked tests (Federal Trade Commission (FTC), International Organization for Standardization (ISO)).

Data sources: Searched from November 1999 to November 2000 internet databases of industry documents (www.pmdocs.com, www.rirtdocs.com, www.lorillarddocs.com, www.bw.aalatg.com, www.cdc.gov/tobacco/industrydocs, www.tobaccodocuments.org, www.tobaccopapers.org, www. hlth.gov.bc.ca/Guildford, www.cctc.ca/ncth/Guildford, www.cctc.ca/ncth/Guildford2) for documents related to filter ventilation. Documents found dated from 1955 through 1994.

Study selection: Those documents judged to contain the most relevant information or data on filter ventilation related to cigarette taste and compensatory smoking, while also trying to avoid redundancy from various documents deriving from the same underlying data.

Data synthesis: Filter ventilation is a crucial design feature creating three main problems for lower tar cigarettes as measured by official smoking machine testing. Firstly, it misleadingly makes cigarettes taste lighter and milder, and, therefore, they appear less dangerous to smokers. Secondly, it promotes compensation mainly by facilitating the taking of larger puffs. Thirdly, for very heavily ventilated cigarettes (that is, > 65\% filter air dilution), behavioural blocking of vents with lips or fingers is an additional contributor to compensatory smoking. These three effects are found in industry research as well as published research.

Conclusions: Filter ventilation is a dangerous, defective technology that should be abandoned in less hazardous nicotine delivery systems. Health interested groups should test cigarettes in a way that reflects compensatory smoking. Lower tar (vented filter) cigarettes should be actively countermarketed.
R ecently disclosed documents of the tobacco industry give a view of what the industry knew and when they knew it. This review examines the industry's secret reports on cigarette design alongside published scientific literature. Previous reports ${ }^{1-5}$ using industry documents $s^{6-8}$ have discussed in broad terms the design of "elastic" cigarettes that promote "compensation" (the attainment of higher smoke exposures by human smokers of lower tar cigarettes than by standard smoking machines). A summary of compensatory behaviours that can be used per cigarette is shown in the box below. Of course, smoking more cigarettes per day is another form of compensation. This review explores in greater detail how filter ventilation works to make the modern, compensatable cigarette. Our review is not exhaustive. While we were searching the web sites, the contents kept increasing. We do not know when or if they will be complete. We also do not provide a complete review of the documents we found. The literature is very large and often highly redundant. A complete review would require many pages of analysis and be tedious to read. Instead, we offer an analysis of the most informative documents.

When health concerns related to smoking were first raised in the 1950s, cigarette manufacturers responded by introducing filtered cigarettes and began what came to be called the "Tar Derby". Manufacturers competed with one another to reassure health conscious smokers with new, "healthier" products. ${ }^{9}$ By the early 1960s in the USA, some health groups expressed concern that these health claims were not backed by objective scientific data. In 1967, the Federal Trade Commission (FTC) in the USA began a programme to test cigarettes for tar and nicotine yields in cigarette smoke. ${ }^{10}$ The test procedure was essentially the same as developed by researchers at a major US cigarette manufacturer ${ }^{11}$; a machine takes a $35 \mathrm{ml}$ puff of two seconds duration once a minute until a fixed butt length is

\section{Ways to increase smoke intake from each cigarette}

A. Increase total volume of smoke per taken per cigarette

- (1) Take larger puffs

- (2) Take more puffs

- a. smoke to a shorter butt length

- b. puff more frequently

B. Increase concentration of smoke per puff

- (1) Block vents on heavily vented cigarettes (> 65\% air dilution) with lips, fingers, or tape

- (2) Increase puff velocity (lowering filter effectiveness)

- (3) Remove filters

reached ( $23 \mathrm{~mm}$ or overwrap plus $3 \mathrm{~mm}) .{ }^{10}$ The International Organization for Standardization (ISO) adopted the same parameters in the 1980s, with slight modification (the fixed butt length was defined as FTC, with an additional criterion of filter plus $8 \mathrm{~mm}){ }^{12}$ Standard cigarette testing is now conducted in the USA, UK, Australia, Japan, and other countries. ${ }^{13}{ }^{14}$ The official smoking machine tests for smoke yields (tar, nicotine, and later carbon monoxide) provides the basis for judging cigarettes lower and lower in smoke yield. In 1992, the European Union legislated a maximum tar yield of $15 \mathrm{mg}$; this was lowered to $12 \mathrm{mg}$ in 1998 and another reduction to $10 \mathrm{mg}$ is under consideration. ${ }^{14}{ }^{15}$ Standard tests have contributed to competition for lower tar and nicotine cigarettes.

Abbreviations: BAT, British American Tobacco; FTC, Federal Trade Commission; HSS, human smoking simulator; ISO, International Organization for Standardization; PM, Philip Morris Tobacco Company; PPU, puffing power units; RTD, resistance to draw; SPT, stain pattern technique; TPM, total particulate matter 


\section{DATA SOURCES AND SEARCH PROCEDURE}

To locate relevant industry documents, the following databases were searched repeatedly from November 1999 to 10 November 2000: Www.pmdocs.com; www.rjrtdocs.com; www.lorillarddocs.com; www.bw.aalatg.com; www.cdc.gov/ tobacco/industrydocs; www.hlth.gov.bc.ca/Guildford; www. cctc.ca/ncth/Guildford; www.cctc.ca/ncth/Guildford2; www. tobaccodocuments.org; www.tobaccopapers.org. Key search terms included: dilution, air dilution, filter dilution, ventilation, filter ventilation, tip ventilation, vent, vent blocking, occlusion, lip occlusion, insertion depth, puff volume, puff parameters, resistance-to-draw, draw resistance, flow rate, smoker-product interaction, smoking behaviour/behaviour, product development (in conjunction with a particular brand), focus group, test market, product testing, product evaluation, irritation, harshness, impact, taste, compensation, compensatory smoking, elastic, elasticity, compensatable/ compensatible, Actron, low tar, lowest tar, $1 \mathrm{mg}$ tar, ultra light, Light, lights, brand switching, switching study, Kozlowski, FTC, testing, yield, tar yield, nicotine yield, CO yield, TPM, delivery, smoke delivery, human smoking, simulator studies, human smoking simulator (HSS). When appropriate documents were found, names associated with the project (for example, authors, supervisors, recipients) were used as search terms to locate additional relevant documents.

We printed about 250 documents. One notes a preponderance of Philip Morris Tobacco Company (PM) documents. This may be because of the ease with which the PM archives could be searched using keywords; other companies' sites were less user friendly. Table 1 shows a chronology of documents used in this review. This exhibit indicates the primary way in which the document relates to one of the three themes of the review: (1) filter ventilation produces a lighter taste ("taste"); (2) filter ventilation causes larger puffs to be taken by smokers ("puff volume"); and (3) high levels of filter ventilation are subject to blocking with lips or fingers ("vent blocking").

\section{DATA SYNTHESIS}

\section{Filter ventilation}

For over three decades, cigarette filter ventilation has been the major design feature for reducing the official machine smoked, standard tar, nicotine, and carbon monoxide (CO) yields of cigarettes. ${ }^{14}{ }^{16}$ Ventilated filters are now common on cigarettes sold in the USA, Canada, and the UK, and multivariate analyses indicate that ventilation has a major effect on standard tar, nicotine, and carbon monoxide yields. ${ }^{4}$ Filter ventilation is not a specialised topic pertinent to only a few cigarette brands. Lower standard tar cigarettes are nearly always ventilated filter cigarettes and ventilated filter cigarettes are nearly always lower standard tar cigarettes.

Air dilution is introduced into the mainstream smoke by means of tiny vent holes on the filter. ${ }^{17}{ }^{18}$ Essentially, smoke is replaced with air in the standard puff, and this also causes less smoke to be produced at the burning coal. ${ }^{19}$ There are also some subtler effects. ${ }^{20}$ The reduced draw on the burning cigarette coal also reduces the temperature of the coal, which can change the nature of the smoke. The smoke moves through the filter at a lower velocity because of ventilation. ${ }^{21}$ There appear to be only two ways to reduce carbon monoxide yields: (1) increase filter ventilation or (2) increase cigarette paper porosity (air flow through the paper itself). A manual for cigarette makers, "Cigarettes a la carte," gives a good explanation of the basic principles. ${ }^{22}$ Using filter ventilation as a sole device leads to many more puffs on a cigarette, because so little tobacco is consumed with each puff of a heavily vented cigarette (for example, $>65 \%$ dilution). "Cigarettes a la carte" explains that methods must be employed to increase the static

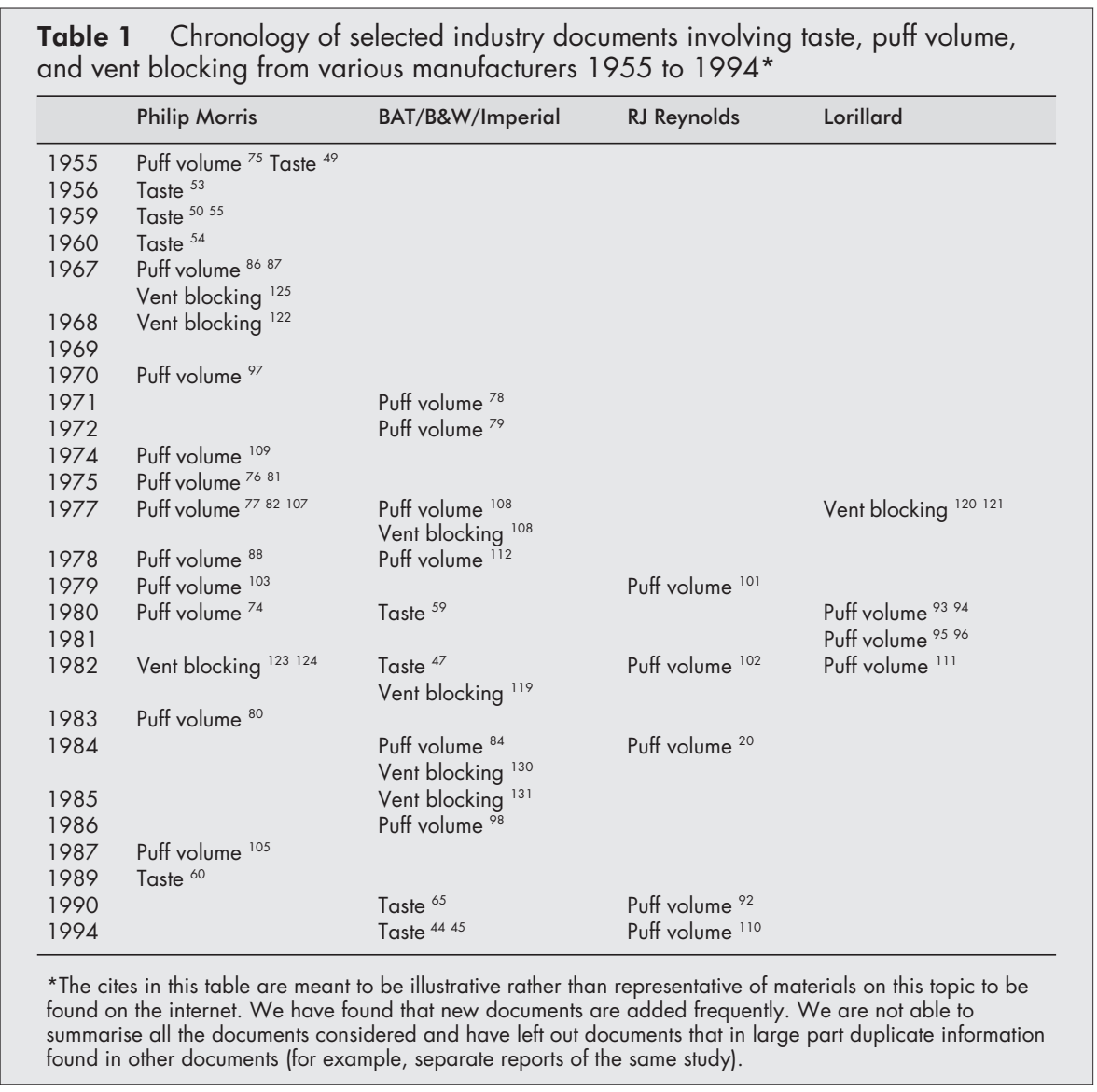


burn rate- the amount of tobacco burned between puffs- to deal with this issue. ${ }^{22}$

\section{Development of ventilation}

In 1983, PM conducted an internal seminar on the development of filter ventilation and low delivery cigarettes. ${ }^{23}$ This seminar describes the rapid rise of vented cigarettes in the USA. PM's first attempt at a ventilated cigarette occurred with SPUD in the mid 1950s, when three slits were introduced into the paper before the filter. In 1970, Marlboro 100 was the first PM product to use mechanical perforation in regular production, shortly followed by Alpine and Marlboro menthol 85s. In terms of the overall market, only $7 \%$ of cigarettes were ventilated in 1975 , rising to $20 \%$ by 1977 . In 1980 , ventilated filter cigarettes represented $50 \%$ of the market. Eighteen months later, $80 \%$ of cigarettes sold were ventilated-only $12 \%$ of filter cigarettes were unventilated by 1982 . By the time of the seminar, PM had introduced dilution into all filter cigarettes, as had RJ Reynolds. Lorillard was diluting $94 \%$ of its filtered products. The American Tobacco Company (then an independent company) was diluting $57 \%$ of its filter cigarettes. Brown \& Williamson, and Liggett were both using dilution in less than a third of their filter cigarettes. The report does not describe ventilation trends in other countries, but notes that by 1981, low tar cigarettes comprised $46 \%$ of the Canadian market and negligible proportions in other countries.

Cigarette filter ventilation provides a straightforward, cost effective way to reduce the standard (as measured by FTC and/or ISO methods) toxin yields of cigarettes. ${ }^{19}{ }^{22}$ It was key to compliance with the European Union's regulations on maximum tar yields. ${ }^{24}$ (Marlboro and Marlboro Light cigarettes have been found to have twice as much ventilation in the UK as in the USA ${ }^{4}$ ). But, the official smoking test creates yield numbers that have little relation to actual human smoke exposures. ${ }^{25} 26$ Indeed, published smoker exposure studies have seen little difference in biomarkers of exposure among smokers of Light, Ultra Light, and lowest tar brands. ${ }^{26}{ }^{27}$ Recent reviews of the disease effects of lower standard tar cigarettes find little support for actual risk reduction as a result of the use of such cigarettes. ${ }^{28} 29$

Numbers from official tar tests have given regulators the impression that something was being done to reduce the toxicity of cigarettes to human smokers, while at the same time industry documents show that cigarettes were being designed to be "elastic" - yielding more smoke to human smokers than to smoking machines. ${ }^{15}$ It is excellent public relations for cigarette manufacturers to appear responsive to governmental and consumer encouragement for less hazardous cigarettes. It should be a public relations disaster to reveal that the industry was aware of compensatory smoking for decades, knew the machine tests underestimated actual smoke exposure, and designed cigarettes to beat the machines. ${ }^{125}$

Our review focuses on three main issues with low tar, ventilated cigarettes. Firstly, the effect of vents on the perception of "lightness" and "less irritation" is critical because it constitutes compelling (but misleading) sensory evidence that a low tar cigarette really has lower tar. In other words, because vented filter cigarettes feel milder, smokers act as if they are less toxic. This combines with the use of descriptors such as Light or Mild to give a dangerous perception of risk reduction. The second issue is that increased ventilation facilitates increased puff volumes, a key means of compensatory smoking. For best selling, vented filter cigarettes in the Ultra Light and Light range, increased puff volume can achieve compensation so well that behavioural vent blocking is superfluous. The third issue is behavioural vent blocking, which is important when increased puffs will not comfortably provide ample compensation. For two decades, Kozlowski and colleagues have investigated the problem of filter vent blocking with the lips and fingers of smokers. ${ }^{30-34}$ This research has made it clear that blocking as a means of increasing yield applies mainly to the most heavily ventilated, lowest standard tar cigarettes. ${ }^{35} 36$

\section{The persuasive testimony of the senses: Lights do taste lighter}

The "lighter" taste of Lights became apparent to us during our national survey research on smoker perception of Light and Ultra Light cigarettes. ${ }^{37-41}$ Focus group participants ${ }^{37}$ told us repeatedly and clearly that they thought Lights tasted lighter and milder and felt easier on the chest. For example, one participant described the aches in his chest he suffered if forced to smoke Marlboro "Reds", rather than his usual Marlboro Lights, at parties. Such findings have been well known to the industry for many years. ${ }^{42-47}$ Because of such dramatic perceptual evidence, smokers are understandably reluctant to accept scientific findings that Light cigarettes are not less dangerous than higher standard tar cigarettes. Smokers may believe that, although others may not experience risk reduction by using Lights, their perception tells them otherwise.

Filter ventilation tends to make cigarettes taste "lighter", thereby supporting the consumer's perception that lower tar cigarettes deliver less tar and nicotine as well as diminished dangers to health. Air diluted smoke tastes, if you will, airier. ${ }^{16}{ }^{48}$ The more air added by dilution, the milder and more air cooled the smoke. This reduces the overall perception of "harshness" and increases the perception of mildness. ${ }^{37-39} 4950$ A quote from a Philip Morris memo is telling. In describing their reasons for ventilating cigarettes, a researcher notes that “... if they [consumers] can see it's longer burning_can taste its mildness-and be shown it's cooler, that this would bring credibility to our advertising." ${ }^{\prime 9}$

Mildness and lightness have been important marketing themes to reassure smokers that cigarettes are less risky. ${ }^{51}$ The popular theory of cancer around the turn of the 20th century held that strong tobaccos caused oral cancers through irritation. ${ }^{52}$ Cigarettes were promoted as a safer alternative to cigars because they were milder. Even before the introduction of filter cigarettes, mildness and lightness were important advertising themes. ${ }^{51}$ The very first nationally advertised cigarette brand in the USA, RJ Reynolds's Camel in 1913, was promoted as milder than other cigarettes of the day. ${ }^{51}$

Nearly 50 years ago in 1956, a confidential memo was written to the most senior executives at PM discussing "new product advantages for ventilated cigarettes". ${ }^{53}$ These included decreased carbon monoxide delivery and "subjectively decreased irritation by the smoke". This theme of decreased irritation is echoed in other documents from the period. ${ }^{555}$ The memo goes on to note: "Decreased irritation is desirable not only from the subjective viewpoint but also as a partial elimination of a potential cancer hazard..$^{153}$ Of course, recent epidemiological evidence has found increases in certain lung cancers with lower tar cigarettes. ${ }^{5657}$

In 1979, PM performed taste tests of ventilated and unventilated versions of regular Marlboro with equal standard tar ratings. They found that the diluted version was rated as "milder" and better tasting. ${ }^{58}$ One year later, a British American Tobacco Company (BAT) study revealed that increasing ventilation from 0 to just $12 \%$ significantly reduced "impact" and irritation of the mouth, nose, and throat. ${ }^{59}$ A 1989 PM test market study of a $9 \mathrm{mg}$ tar (33\% ventilation) Marlboro Light in Korea found that the more ventilated cigarette was judged milder and preferred to a regular Marlboro Light ( $11 \mathrm{mg}$ tar, $25 \%$ ventilation). ${ }^{60}$ Given that smokers compensate easily for such small tar differences as a result of ventilation by increasing puff volume (see next section for an elaboration of this point), we expect that smokers were actually ingesting similar concentrations of tar and nicotine from each version of Marlboro Light even though these lower standard tar cigarettes tasted milder. The perception of lightness seems to derive, at 
least in part, from the level of ventilation present in the cigarette. One might wonder if the issue of behavioural vent blocking (discussed below) is at odds with the issue of vent induced lighter taste. After all, if vents were completely blocked might not the cigarette taste become the same as its unventilated counterpart? Sweeney and colleagues ${ }^{35}$ found that, indeed, blocked cigarettes were rated as significantly harsher and hotter than unblocked ones. But most behavioural vent blocking is incomplete, often diminishing ventilation levels by $50 \%$ or $25 \% .{ }^{61}{ }^{62}$ While Zacny and colleagues ${ }^{63}$ reported that the unblocked $1 \mathrm{mg}$ standard tar cigarette (that is, fully ventilated) was rated as much less harsh than the same cigarette fully blocked (that is, unventilated), a $50 \%$ blocked cigarette received intermediate ratings-still less harsh than a fully blocked cigarette.

Interestingly, consumers can be troubled if a lower tar cigarette has too strong a taste. Consider Brown and Williamson's (a subsidiary of BAT) Barclay brand. Barclay has ventilation channels that are subject to reduced ventilation whenever a smoker places the cigarette in the mouth. ${ }^{64}$ This compensatory smoking system produces a strong taste, so much so that many lowest tar smokers rejected the brand. ${ }^{65} 66$

Ventilation is a key, but not the only, contributor to perceptions of cigarette harshness. The quality of the tobacco blend, chemical additives (for example, ammonia), cigarette circumference, moisture level, and even tipping paper colour have been found to influence a smoker's perception of the strength and irritation level of a cigarette. ${ }^{67-73}$

\section{Bigger puffs are the key to compensation for most ventilated filter cigarettes}

Cigarettes vary in how hard the smoker has to puff on them to produce a given volume of smoke. An industry scientist noted this is not an issue for smoking machines, which take a $35 \mathrm{ml}$ puff regardless of the effort involved. ${ }^{74}$ Other things being equal, ventilated filter cigarettes have lower resistance to draw (RTD). This effect was known as early as 1955, and is discussed in an internal Philip Morris memo on the effects of early ventilation designs. ${ }^{75}$ A lower filter RTD (and higher dilution level) facilitates the taking of bigger puffs. ${ }^{767}$ This means that smokers can easily take larger puffs on the cigarette with little added effort. To get an idea of the magnitude of the effect, consider Zacny and colleagues' study. ${ }^{63}$ For an unblocked (that is, fully ventilated-66\%) $1 \mathrm{mg}$ standard tar cigarette the average RTD was $92.5 \mathrm{~mm} \mathrm{H}_{2} \mathrm{O}$. In contrast, fully blocking the same cigarette (equivalent to making it unventilated) doubled the RTD to $184.4 \mathrm{~mm} \mathrm{H}_{2} \mathrm{O}$.

RTD appears to have been a significant concern to low tar cigarette designers in the 1970s and 1980s. ${ }^{76}{ }^{78-80}$ Independent research programmes at $\mathrm{PM}$ and BAT investigated the effects of RTD on smoker behaviour, in particular puff profiles. At BAT in 1972, Creighton led a number of studies on draw resistance, ventilation and smoking behaviour. ${ }^{78}$ One found that "subjects took more puffs of very much larger volume from the ventilated cigarette, but showed no difference in the way they inhaled smoke." ${ }^{79}$ Studies at PM concluded that there were optimal dilution/RTD ratios for consumer acceptance. ${ }^{80}$

The dilution level of a ventilated cigarette determines how large a puff smokers must take to compensate fully. A 1975 PM study states that "filter dilution by itself causes a smoker to change his puffing pattern." ${ }^{\prime 1}$ Similarly, a 1977 PM study found that "the dilution level itself influences the smoker's [puffing] profile to a great extent."[ 82] Sutton and colleagues $^{83}$ reported that the relation between dilution level and compensating puff volume is curvilinear:

Percentage increase in puff volume $=[\%$ dilution $/(100-$ $\%$ dilution)] $\times 100$.

As dilution increases, puff volume to compensate increases exponentially. We can illustrate this simple model using recently tested cigarettes from the USA, Canada, and the UK. ${ }^{4}$ Assuming a $35 \mathrm{ml}$ standard puff, full compensation for the dilution would be expected on a cigarette with $14 \%$ dilution (for example, Craven Full Flavor; Canada) with a small puff volume increase $(\sim 15 \%$, from $35 \mathrm{ml}$ to $40 \mathrm{ml})$. A smoker of $40 \%$ diluted Dorchester Extra Milds (UK) might need to take a $58 \mathrm{ml}$ puff (a 67\% increase) to achieve full compensation. In contrast, on highly ventilated Carlton 100s (USA) or Benson 8 Hedges Ultra Lights (UK) (both $\sim 83 \%$ diluted), heroically large $206 \mathrm{ml}$ puffs might be required. The best selling cigarette in the USA, Marlboro Light, is just 23\% diluted, and a puff of only $45 \mathrm{ml}$ would likely fully compensate. The exact puff volumes needed for compensation are in practice somewhat smaller than those estimated using this simple model. Higher velocity, bigger puffs produce greater compensation than do lower velocity puffs of the same size. ${ }^{84}$

Increased puff volume is a very likely mode of compensation when it can be performed with only a modest amount of effort (that is, for a Light cigarette with low to moderate ventilation). For a heavily ventilated cigarette (for example, the $65 \%$ diluted, $1 \mathrm{mg}$ tar), increasing to a puff volume within a comfortable range (for example, about $50-80 \mathrm{ml}$ ) alone generally would not provide adequate compensation. Hence, other forms of compensation become more important in this class of cigarettes. Also, the above figures are on a per puff basis. For compensatory smoking, total puff volume per cigarette (puff volume per puff $\times$ number of puffs) is more important than the volume per puff.

The lighter feel of ventilated cigarettes may further facilitate increased puff volumes because inhibitory oral and respiratory cues are milder. ${ }^{85}$ When a smoker increases his puff volume, he receives more smoke per puff from the cigarette (which compensates for reduced yield), but also receives more air. The larger puff feels "lighter" to the smoker than if he had taken a smaller, more concentrated puff of equivalent yield from an unventilated or less ventilated cigarette.

In 1967, scientists at PM wrote a memo: "A study of the effect of air hole blockage on gross puff volume in air-diluted cigarettes." ${ }^{\prime 6}$ The mean "gross puff volume" for the test cigarette without filter vent holes was significantly less $(38.17 \mathrm{ml})$ than for the test cigarette with holes $(45.48 \mathrm{ml})$. The test cigarette was apparently $21 \%$ diluted, based on another memo. ${ }^{87}$ They noted this as "further evidence that smokers adjust puff intake in order to maintain constant smoke intake." ${ }^{\prime 86}$ In short, smokers were taking larger puffs on the ventilated cigarette. A PM study of a Merit-type cigarette using a human smoking simulator (HSS-a machine that records smoker's puff profiles and replicates them) showed that the recorded human volume of $57.8 \mathrm{ml}$ doubled the FTC $\operatorname{tar}(9 \mathrm{mg}$ to $18 \mathrm{mg})$ and nicotine $(0.62 \mathrm{mg}$ to $1.3 \mathrm{mg})$ yields of the cigarette. ${ }^{88}$ Another PM HSS study notes that "standard puffs of $35 \mathrm{cc}$ volume repeated at one minute intervals are seldom seen among smokers.." ${ }^{\prime 77}$ Still another PM simulator study noted that under simulated human smoking conditions (exact parameters not reported) a 55\% diluted $2 \mathrm{mg}$ tar test cigarette showed a tar yield increase of five times; a Now (65\% dilution) showed a six times increase over standard yield $(2 \mathrm{mg})$; a Carlton 70 ( $80 \%$ diluted) showed a yield increase of 10.5 times standard yield $(1 \mathrm{mg}){ }^{80}$ Such findings have been observed repeatedly, outside ${ }^{63}{ }^{89-91}$ and inside $e^{77}$ 82-105 $^{92-1}$ the industry. In the early 1980s, PM scientists concluded that "[r]esults from a series of puff parameter manipulations made on the smoking machine indicate that puff volume is the critical variable in determining nicotine delivery to the smoker". ${ }^{106}$

Much of the laboratory research on smoking has used cigarette holders to measure puff volume and puff numbers. ${ }^{107} 108$ This equipment prevents vent blocking with lips and shows how much compensation is possible without vent blocking. Two PM studies, for example, show how much puffing a smoker can do on a $1 \mathrm{mg}$ tar cigarette if he cannot block vents. In a study of college student smokers, one subject was 
observed to take a total puff volume of $1397 \mathrm{ml}$ (number of puffs was not reported) from a single Carlton cigarette, while the machine smoked volume was only $315 \mathrm{ml}$, over a fourfold difference. ${ }^{109}$ Compare this to the total puff volume of $479 \mathrm{ml}$ taken by the same subject on a Marlboro, which had a machine smoked volume of $329 \mathrm{ml}$. The mean puff volume across smokers of the Carlton was $713 \mathrm{ml}$. In a separate study of an experimental $2 \mathrm{mg}$ product, a subject was observed to take $100 \mathrm{ml}$ puffs every 15 seconds on a Carlton, for a total puff volume of $1399 \mathrm{ml}$ on a single cigarette. ${ }^{107}$ These individuals were working hard to smoke these cigarettes.

Industry scientists have also been interested in interactions between ventilation type and puff volume. For example, researchers at RJ Reynolds Tobacco Company compared laser, mechanical, and electrostatic perforation types. ${ }^{20}$ Laser perforations were found to promote compensation with increased puff volumes. That is, as puff volumes increased, filter air dilution decreased most notably with laser perforations. Other RJ Reynolds researchers tested yield differences of different tobacco blends with various perforation styles and equivalent dilution levels. ${ }^{110}$ Cigarettes were smoked both according to FTC procedures and "50/30" procedures ( $50 \mathrm{ml}$ puff, every 30 seconds). Two rows of "slot" perforations gave the same nicotine $(0.11 \mathrm{mg})$ as did two rows of "hole" perforations under FTC conditions, but gave more nicotine under the "50/30" condition: $0.67 \mathrm{mg}$ (a 509\% increase) versus $0.53 \mathrm{mg}$ (a 382\% increase). Researchers at Lorillard noted that if a cigarette had perforations arranged to cause flow turbulence in the filter, then smoke yields could be increased under intense puffing more than would be expected volumetrically. ${ }^{111}$

Within the PM research programme, it was well known that the machines were not an accurate representation of human smoking on low tar cigarettes and that filter ventilation promoted compensatory smoking. ${ }^{109}$ In 1974, Helmut Wakeham, one of the most senior executives at Philip Morris, gave a presentation to stockholders. He explained, "people smoke in such a way that they get much more than predicted by machine. This is especially true for dilution cigarets. [sic]"109

Leading scientists at BAT knew the special value of filter ventilation for compensatory smoking. Creighton conducted studies comparing the effects of two methods of diluting cigarette smoke: paper porosity or filter ventilation. He found that using high porosity paper made it much more difficult for smokers to compensate, because taking larger puffs would actually reduce delivery. ${ }^{112}$ He noted that, while it would be possible to compensate for paper porosity by using low velocity, long duration puffs, most smokers would not be able to do this comfortably. However, he concluded: " . . . a cigarette constructed with low paper porosity but with filter tip ventilation would more readily allow a smoker to take a higher delivery of smoke by increasing the velocity of puffing." ${ }^{112}$ Creighton summarised that this would provide BAT with "a marketing opportunity to offer a LOW to LOW TO MIDDLE delivery product when smoked by machine, which could be a LOW TO MIDDLE to MIDDLE delivery product when smoked by the smoker." ${ }^{\prime 12}$ BAT research also noted that the effects of puff volume increases were larger in higher dilution cigarettes. ${ }^{113}$

Filter ventilation is a key contributor to the phenomenon of compensation because of its effects of increasing the puff volume taken by smokers. The industry was well aware of such volume based compensation and appears to have designed cigarettes to take advantage of it.

\section{Vent blocking as an additional mode of compensation}

In 1980, Kozlowski and colleagues began exploring the problem of smokers blocking filter vents, usually unwittingly, with fingers or lips and increasing smoke exposures above standard yield levels. ${ }^{30}$ Blocking $50 \%$ of filter vents increased standard tar yields from $4.4 \mathrm{mg}$ to $7.0 \mathrm{mg}$ tar and nicotine from $0.45 \mathrm{mg}$ to $0.73 \mathrm{mg}$. Subsequent studies have found evidence of some

\section{Model of vent blocking}

Vent blocking is more likely to occur in:

A. Cigarette designs in which:

- (1) blocking increases nicotine and tar yields (generally, the greater the ventilation level, the greater the effect of blocking on nicotine and tar yields)

- (2) other forms of compensation (increased puff number, puff volume, or puff velocity) do not adequately compensate for reduced standard yields (this will be more likely when ventilation level greater than $65 \%$ ) $\left(c f^{35}\right)$

and

B. Smokers who:

- (1) seek nicotine and tar

- (2) have had a chance to learn by trial and error the effects of vent blocking $\left(\mathrm{cf}^{135}\right)$

degree of vent blocking in about $50 \%$ of vented cigarettes (Light or Ultra Light)..$^{32} 34112114115$ Our more recent studies of human smokers blocking vents have indicated that vent blocking mainly has effects on smoke exposures (as measured by expired alveolar carbon monoxide (CO)) in the lowest tar and nicotine cigarettes (1-2 mg standard tar). Behavioural blocking appears to have negligible effects on exposures in best selling Light cigarettes (8-14 mg standard tar) and has little effect on the Ultra Light brands studied (4-6 mg tar)..$^{35} 36$ Before continuing, consider the model of vent blocking presented in the box below. This model presents vent blocking as a product of cigarette design and smoker variables.

Industry scientists have challenged in print ${ }^{62116} 117$ the assertion that smokers' blocking filter vents with lips or fingers is a substantial mode of compensation for low tar cigarettes. Reading these published industry reports might convince one that cigarette manufacturers have nothing to hide on this issue. One might assume from their published reports that their technical investigations have uncovered little to support evidence presented in the peer reviewed scientific literature since the 1980s. One gets the impression of winning cards being put on the table by the cigarette industry. These papers, however, make no mention of the taste and puff volume issues influenced by filter ventilation as discussed above.

The industry's counter-arguments to the importance of vent blocking primarily rest upon two assertions. The first claim is that vent blocking does not happen very often. This argument is based on saliva based estimates of mouth insertion depths, which differ little between ventilated and unventilated cigarettes. The second claim is that, on those rare occasions when vent blocking occurs, it increases tar and nicotine yields little because most blocking occludes at most $50 \%$ of vents. At that level, they assert, the curvilinear effect of blocking on ventilation level is relatively small.

We have found three main deficiencies in the public industry reports. Firstly, the saliva based measures are seriously limited, underestimating mouth blocking and ignoring finger blocking. Secondly, because the large majority of vented cigarettes do not have a high level of dilution, the lack of attention to degree of ventilation instead of presence versus absence of ventilation obscures significant vent blocking effects in less popular, heavily ventilated cigarettes (that is, $>65 \%$ ventilated). Thirdly, the effects of vent blocking on tar and nicotine yields vary from brand to brand depending on the complex of design features-some show small effects, some large effects. The published industry reviews may have used brands with relatively small effects.

The industry scientists seem to have ignored the extensive machine smoking studies by Rickert and colleagues on Canadian cigarettes, ${ }^{118}$ which have shown significant vent blocking effects, particularly when more realistic smoking conditions 
are used. In Rickert's study, puff volume was increased to $48 \mathrm{ml}$, puff duration was increased to 2.4 seconds, and puff interval was reduced to 44 seconds. Under these conditions, lowest tar cigarettes (1 $2 \mathrm{mg}$ standard tar) showed a $130 \%$ $(0.22 \mathrm{mg})$ increase in nicotine yield, while Ultra Light (3-5 mg standard tar) and Light (6-14 mg standard tar) cigarettes showed yield nicotine yield increases of $57 \%(0.31 \mathrm{mg})$ and $36 \%(0.41 \mathrm{mg})$ respectively when $50 \%$ of vents were blocked. ${ }^{118}$ Tar yields in Lowest Tar cigarettes increased 160\% $(2.5 \mathrm{mg})$, compared to $63 \%(4.0 \mathrm{mg})$ and $38 \% \quad(5.5 \mathrm{mg})$ increases in Ultra Lights and Lights. Carbon monoxide yields in Lights increased by $36 \%$ (4.7 mg), while Ultra Light brands increased 75\% (4.9 mg); Lowest Tar brands increased 150\% (2.6 mg).

The industry researchers also have omitted details from some cited studies or any mention of other studies that support the position that vent blocking is a problem. One notable omission from Baker and Lewis ${ }^{62}$ is a 1982 BAT study of vent blocking on a $1 \mathrm{mg}$ tar cigarette smoked under various puffing conditions. ${ }^{119}$ Experimenters systematically blocked the vent area with patches of increasing size. Here, the data suggest that vent blocking does significantly increase yields, particularly under more realistic smoking conditions. Under FTC conditions, the cigarette delivered $1.29 \mathrm{mg}$ total particulate matter (TPM) unblocked, $1.69 \mathrm{mg}$ half blocked, and $8.44 \mathrm{mg}$ fully blocked. If conditions were increased to " $50 / 30$ " ( $50 \mathrm{ml}$ puff every 30 seconds), the cigarette delivered $4.52 \mathrm{mg}$ TPM unblocked, $6.51 \mathrm{mg}$ half blocked, and $20.9 \mathrm{mg}$ fully blocked.

Another BAT study not discussed by Baker and Lewis ${ }^{62}$ is one by Creighton examining smoking behaviour on low delivery cigarettes. ${ }^{108}$ Creighton notes that, even with his small number of subjects $(n=10)$ : “There were some abuses of the cigarette design. These took place outside the behavioural laboratory. It was observed that at least one subject learned that by placing the cigarette further into the mouth, the ventilation holes could be covered up and smoke deliveries increased. It was also noted that the fingers used to hold the cigarettes could be conveniently placed to cover up some of the ventilation holes. One subject was seen to cover the ventilation holes with clear adhesive tape" [emphasis added] ${ }^{108}$

We expect that Baker and colleagues were unaware of the internal Lorillard memo from one scientist to a supervisor in 1977. ${ }^{120}$ Ihrig wrote to Schulz that he and colleagues had devised a way to make 1-2 mg standard tar cigarettes actually deliver around 4-5 mg tar to smokers. The system depended on human lips covering filter vents that were not being covered by the official FTC cigarette holder. Ihrig wrote: "These experiments conclusively demonstrate the feasibility of a filter bypass. Since filters can be designed to deliver more taste (tar) to the smoker than tests indicate, the current tar and nicotine procedure is vulnerable to abuse ..." ${ }^{120}$ It should be noted that Schulz immediately rejected the idea as unethical. ${ }^{121}$ Ihrig later went on to join Norman in investigating puff volume effects on compensation. ${ }^{93-95}$

PM conducted several studies on the effects of vent blocking, both before and after the first peer reviewed studies were published. ${ }^{122-126}$ In 1967, PM scientists noted that “...some of these [ventilation] holes are likely to be occluded under normal smoking conditions, whereas no occlusion is likely to occur when the cigarettes are machine smoked for analysis." ${ }^{125}$ A study from 1982 notes that a Merit UL went from $4.5 \mathrm{mg}$ tar at standard conditions to $7 \mathrm{mg}$ with $50 \%$ of vents blocked by fingers. ${ }^{123}$

\section{Detecting vent blocking}

In 1980, Kozlowski and others described a "stain pattern" technique (SPT) for unobtrusively detecting the occurrence of vent blocking with fingers or lips. ${ }^{30}$ Basically, this technique evaluates the tar stain on the mouth end of the filter, a stain spreading toward the edge of the filter indicating the presence of vent blocking. In cases of extreme blocking, one will note a fairly uniform tar stain across the filter. Trained raters are able to produce reliable and valid scores using this technique. The SPT has been validated 30313315127 and can reliably detect the presence or absence of vent blocking (but not degree of blocking, as was initially suggested) in many brands (Craven A Special Mild, Carlton, Now, Virginia Slims Ultra Light, Virginia Slims Light, Merit Ultima, Cambridge Ultra Light, Merit, Basic Light, Doral Ultra Light, GPC Ultra Light, Doral Light, Camel Light). It does not work for Barclay which uses the plastic-vent-channel Actron filter. This filter was judged by a US court as not able to be assessed by the FTC smoking machine method because of the ease with which its ventilation system could be compromised. ${ }^{64}$

Baker and Lewis ${ }^{62}$ note that the stain pattern can vary because of factors such as hole size, hole depth, and number of holes. ${ }^{128}{ }^{129}$ But they present no evidence that this presents a significant problem for SPT. They also cite work by Shibata (their reference 16), which suggests that the technique might not work for cigarettes less than $69 \%$ ventilated-but, ironically, the Shibata research presented indicates that the pattern technique should work best for more heavily ventilated cigarettes (the very brands proposed to be most subject to vent blocking). The stain pattern studies cited above demonstrate that the system works for several popular brands. The industry prefers saliva based measures of insertion depth as an index of vent blocking. ${ }^{62116117}$ However, these methods can be impaired by lip dryness and also miss finger blocking entirely unless the smoker licks his fingers. Proponents admit that up to $20 \%$ of imprints are unscorable. ${ }^{117}$

\section{Hiding the few heavily vented cigarettes in a "haystack" of lightly vented ones}

The large majority of ventilated cigarettes are not highly diluted (that is, $<40 \%$ dilution). Consider three popular brands: Marlboro Lights, bestsellers in the USA $(22.5 \%$ dilution), Marlboro (10.2\% dilution), and Winston (11.7\% dilution). ${ }^{4}$ Analyses that focus solely on differences between vented and non-vented cigarettes obscure interesting effects. Baker and Lewis conclude that insertion depths are the same for ventilated and non-ventilated cigarettes-without attention to dose-response issues. A BAT Suisse study of cigarette insertion depths ${ }^{130}$ notes: "Analysis of individual brands clearly indicates that highly ventilated cigarettes are inserted deeply into the smoker's mouth and consequently the ventilation level is reduced during normal human smoking [emphasis added]." A $1 \mathrm{mg}$ tar, $0.1 \mathrm{mg}$ nicotine, $78 \%$ diluted brand had $43 \%$ of insertion depths beyond the vents, while a full flavour brand ( $16 \mathrm{mg}$ tar, $1.2 \mathrm{mg}$ nicotine, $17 \%$ diluted) had only $22 \%$ of scores beyond the vents (both brands had vents at $11-13 \mathrm{~mm}) \cdot{ }^{130}$ Further, more fully blocked cigarettes were seen in the lowest yield category than any other category (fig 1). Baker and Lewis ${ }^{62}$ also presented results from Canada (their reference 20) to support the contention that insertion depths do not differ between ventilated and unventilated products. A CORESTA abstract ${ }^{131}$ found on the internet appears to refer to this work and notes: "Insertion depths were greatest for cigarettes in the very low delivery category [emphasis added]." Baker and Lewis omit mention of these findings in their review.

Porter and Dunn ${ }^{116}$ of Canada's Imperial Tobacco (a subsidiary of BAT) examined mouth insertion depths on cigarette butts collected in Montreal, Toronto, and Vancouver. They reported that the insertion depth difference between ventilated and unventilated cigarettes was negligible. Yet, between $4-10 \%$ of butts showed evidence of complete blockage, and 14-20\% showed at least partial vent coverage. ${ }^{116}$ Insertion depths by yield category were not separately considered. The same year, Baker and colleagues ${ }^{117}$ found statistically reliable differences in insertion depths with increasing ventilation 


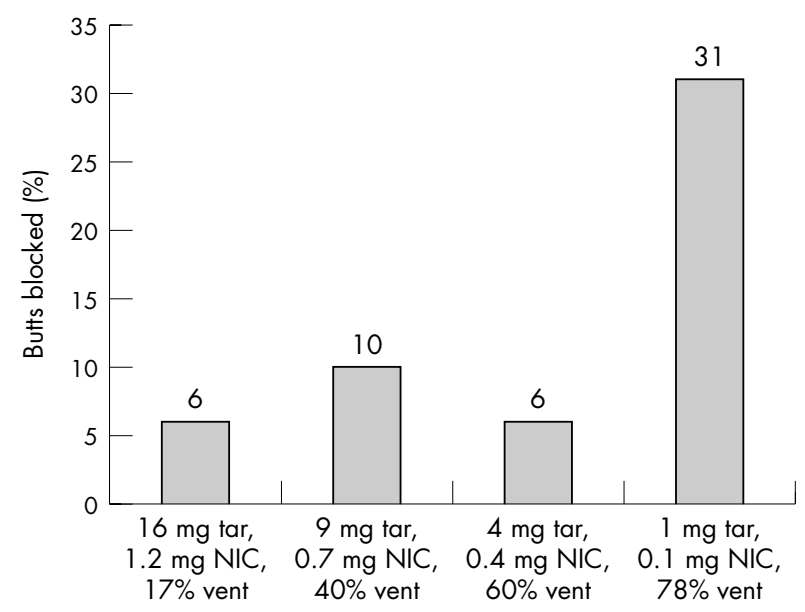

Figure 1 Percentage of butts showing completely blocked vents on various cigarette types (data from unpublished BAT Suisse study ${ }^{130}$ ). Complete vent blocking was defined as by Baker and Lewis ${ }^{62}$ as placing lips $4 \mathrm{~mm}$ or more beyond the ventilation zone. This figure was created from insertion depth data.

levels. Ultra Light cigarette butts were 4.4 times more likely to be completely blocked (6.5\% Ultra Light $v 1.5 \%$ Light). Standard cigarettes were inserted a mean of $7.8 \mathrm{~mm}$, while Ultra Lights were inserted $9.5 \mathrm{~mm}$ (22\% deeper). However, the authors downplay the differential prevalence of vent blocking by yield.

Ferris of BAT (cited by Baker and Lewis, their reference 17) videotaped 133 British smokers of ventilated cigarettes. Analysis of the videotapes showed that smokers' fingers were in contact with the cigarette for all or part of a puff $12 \%$ of the time, while during $81 \%$ of the puffs there was no finger contact with the cigarette. Ten per cent of the puffs could not be assessed. Looking at final puffs, 29\% had smokers' fingers at least partially in contact with the cigarette. Overall, $11 \%$ of participants had fingers in contact with the cigarette for at least one puff. While viewing the videotapes, lip blocking was not assessed. This is especially puzzling given that if one is finger blocking a particular puff, one cannot be lip blocking (that is, the two actions are mutually exclusive on a given puff). A similar curious omission is noted in Philip Morris studies of finger blocking. ${ }^{124}{ }^{125}$ Philip Morris also appears to have known early on that vent blocking may be inconsequential in less ventilated products. A 1982 study notes: "The decrease in dilution from covering a portion of the perforated area can result in an increased delivery to the smoker of highly diluted cigarettes even though the puff parameters decrease. For cigarettes with lower dilution the increase in tar delivery is minimal [emphases added].".124

\section{Working to derive nicotine from lower tar cigarettes}

Smokers select cigarette brands for a variety of biological and psychosocial reasons. ${ }^{132}$ A key biological factor is the psychoactive effects of nicotine from cigarettes. A key psychosocial factor is to smoke a brand that conforms to one's self image. ${ }^{9}$ This self image can include concerns about diseases caused by smoking, and it is clear that smokers tend to consider lower tar cigarettes less risky. ${ }^{39} 133134$ The industry has been aware that high desires to smoke a lower risk cigarette can make a smoker willing to work harder. ${ }^{92-95}$ For example, scientists at Lorillard examined puff volumes (at standard FTC $35 \mathrm{ml}$ as well as $50 \mathrm{ml}$ puffs) on lower tar cigarettes and had an elaborate language to describe the relation between puffing regimens and yields. Norman and Ihrig ${ }^{93}$ summarised these relations using "puffing power functions". Puffing power units (PPU)-defined as the product of the flow rate and RTD (called "pressure drop" in the document)—-served as a measure of the phenomenon. Basically, the increase in PPU represented the extra effort needed to obtain additional tar from the cigarette. An understanding of puffing effort was thought to be critical for very low yield brands, since these were the most likely to be smoked with extra effort to obtain more smoke.

Standard tar yields can be seen as an indicator of how hard a smoker has to work to achieve rewarding doses of nicotine. Higher tar cigarettes ( $>15 \mathrm{mg}$ standard tar in the USA) provide the easiest access to nicotine. Light cigarettes (6-15 mg standard tar) are still easy to get adequate nicotine from, but require some additional (larger) puffing per cigarette. Ultra Light cigarettes (3-5 mg standard tar) will require still more puffing (that is, more effort). The "Lowest" tar category (1-2 mg standard tar) will require more work that most smokers are willing to do, ${ }^{92}$ and those high nicotine smokers who fail to learn by trial and error to block vents may switch back to higher tar cigarettes. ${ }^{132}{ }^{135}$ But not all smokers of Lowest tar cigarettes are working to get high yields from these cigarettes. Some smokers of these cigarettes are simply very light smokers with low nicotine needs; others work hard by blocking filter vents and taking more and bigger puffs and smoking more cigarettes per day to get adequate levels of nicotine from these cigarettes. ${ }^{135}$

Industry research shows that smokers make trade-offs between perceived safety and satisfaction from cigarettes. Highly concerned individuals are more willing to put up with the work needed to get nicotine and the less satisfying taste from the Lowest yield cigarettes. ${ }^{45} 136$ Smokers of Light cigarettes want a brand that makes them seem less foolish to be still smoking, but they do not want to work too hard for nicotine or taste satisfaction. ${ }^{42}{ }^{137-139}$

\section{DISCUSSION AND CONCLUSIONS}

Filter vents are both an effective design feature for the industry and a tragedy for the smoker seeking a less hazardous smoke. The industry gets an inexpensive-to-make cigarette that beats the standard tar tests, ${ }^{1}$ reassures smokers with a lighter taste, and facilitates the taking of bigger, compensating puffs. Smokers can take false comfort from a lighter taste and a consoling name (such-and-such Ultra Light or Light); and their smoking is sustained by satisfaction from bigger puffs on the majority of low tar cigarettes and from blocking filter vents on the relatively rare "Ultra Ultra" Lights (> 65\% air diluted, 1-2 mg standard tar). Cigarettes continue to sell. Smokers continue to die at an undiminished rate. ${ }^{2856}$

\section{Some limitations of reviewing industry documents}

We do not know what further documents are due to be posted on the internet. We could find documents one day that had not been there the day before, searching on the same keywords. Many of the websites do not permit searches for words within documents: If one of our key words did not appear in the title, we may have failed to locate some useful papers that were available. If we had the time to read every document on the internet, we may well have found more information relevant to ventilation. When researching our comments on Baker and Lewis, ${ }^{62}$ we noted that some industry studies they cited were nowhere to be found on either the industry or non-industry websites.

\section{Stop using vents to appear to reduce harm to smokers} If we imagine that manufacturers were motivated to reduce harm to their customers, then the lower tar (vented filter) cigarette should be judged a complete failure. Some of the best evidence of the failure of filter ventilation as a health protecting design feature comes from tobacco industry reports and memos that have been only recently become available because of litigation. Given the triple threat to cigarette smokers (deceptive taste, facilitated puffing, and vent blocking), the ventilated filter cigarette may simply be too dangerous to 
countenance. Arguably the most important design feature in the modern low tar cigarette not only fails to significantly reduce smokers' exposure to toxins, but also misleadingly reduces their health concerns. Filter ventilation, an explicitly defective and deceptive design feature, should be banned as a means of reducing machine smoked yields.

Increased filter ventilation levels can be expected in those countries that are lowering the maximum allowable standard tar and nicotine yields. ${ }^{24}$ Countries considering such maximums also ought to regulate which design changes are permissible to achieve these yields. Prohibiting filter ventilation would require manufacturers to achieve those reductions by other means. The supposedly novel designs of Eclipse and Accord $^{140}$ are ventilated. Governments considering regulation of novel devices should also disallow ventilation as an acceptable design feature on these products.

\section{Health and consumer groups should commission their own two stage testing of cigarettes}

Kozlowski and $\mathrm{O}^{\prime} \mathrm{Connor}^{1}$ proposed a two stage machine smoking test. The first stage would be a current standard test (with a maximum tar yield of $10 \mathrm{mg}$ and maximum nicotine yield of $1.0 \mathrm{mg}$ ). It was proposed that for every $0.1 \mathrm{mg}$ below a $1.0 \mathrm{mg}$ nicotine standard yield the puff volume would be increased by $4 \mathrm{ml}$ and the puff frequency decreased by four seconds. A $0.1 \mathrm{mg}$ standard nicotine cigarette would be smoked with a $76 \mathrm{ml}$ puff every 24 seconds. (These parameters are best estimates in lieu of further machine studies.) Filter vents would be $50 \%$ blocked for machine smoking unless clear instructions are given not to block vents and the vents are clearly marked. While in the best of all possible worlds one would prefer a test involving biomarkers and observation of human smokers linked to specific brands, such assays would take years to develop and be very expensive to use. A two stage machine test, despite clear limitations, could be implemented in the near future. There is no need to wait for the tobacco industry to agree to "compensating" test standards. Such a procedure could take years and might get nowhere. Just as consumer groups (for example, the Consumers Union in the USA) publish the results of their own tests of products, often according to their own procedures, they could do tests of cigarettes that might better inform consumers. Any group is free to say that when cigarettes are tested in fashion $X$, one gets results $\mathrm{Y}$; biases should be toward consumer protection rather than corporate gainsaying.

\section{Cigarettes should be discouraged as a nicotine delivery system}

Smoked tobacco products are much more dangerous to public health than are other nicotine delivery systems. ${ }^{141-143}$ Even if filter vents were eliminated as a design feature, how would compensating puff volumes or puff numbers be controlled? How would fire risks ${ }^{144}$ or second hand smoking risks ${ }^{145}$ be controlled? To fret about designing a "safer" cigarette and to invest further research into controlling specific toxins in cigarettes ${ }^{146}$ may end up being little more than a make work programme for toxicologists who will spend years assessing how many nitrosamines and polyaromatic hydrocarbons dance in a chromatograph $\left(\mathrm{cf}^{147}\right)$. Further research into "safer" cigarettes would serve as a stalling tactic for the industry. From the late 1960s to the late 1970s in the USA, the National Cancer Institute worked in close cooperation with the tobacco industry in an organisation called the Tobacco Working Group. ${ }^{148}$ Among the scientists involved were Gio Gori, Dietrich Hoffman, Ernst Wynder, Helmut Wakeham (PM), and Alan Rodgman (RJ Reynolds). Programme direction came from the National Cancer Institute. Mouse back painting studies were used to evaluate the toxicity of many strains of tobacco. This project is generally viewed as a complete failure to identify a "less hazardous cigarette". Decades of effort have been put into less hazardous cigarettes.

\section{What this paper adds}

Filter ventilation is a nearly ubiquitous design feature in cigarettes. Smokers increase puff volume, number of puffs, and number of cigarettes smoked, and block filter vents to compensate for the smoke yields of lower tar cigarettes as measured by standard smoking machine tests.

This paper explains the complex role of filter ventilation in compensatory smoking as seen in industry documents and published research. Ventilation is found to cause lighter taste, promote larger puffs, and, with heavy ventilation, promote behavioural blocking of vents. Filter vents are judged to be a defective, misleading design feature. Policy and regulation of cigarettes needs to attend to the problems of filter ventilation.

Research and development should be directed toward efforts to find non-burned, non-smoked, nicotine delivery systems ${ }^{143-147}$ and to encouraging current smokers to use such products instead of cigarettes. ${ }^{149}$

\section{Lower tar cigarettes should be aggressively counter marketed}

Evidence is beginning to appear that counter marketing Light cigarettes can be effective. ${ }^{37}{ }^{133}$ The most effective countermarketing efforts may be those that acknowledge the consumer's sensory evidence that Lights feel less harsh than regular cigarettes. ${ }^{37}$ Results of consumer protection focused cigarette tests (see above) could also aid in countermarketing.

In conclusion, vents reduce machine smoked tar and nicotine yields exquisitely. Yet, smokers of standard lower tar cigarettes do not generally get reduced smoke toxin exposures or improved prospects for avoiding tobacco caused death and disability. Research inside and outside the tobacco industry has shown that filter ventilation is a key design feature for the modern lower tar cigarette. We reviewed three special and powerful effects of filter vents that contribute to the dangers of these cigarettes. Firstly, and possibly most noteworthy, ventilated filter cigarettes taste lighter and milder than their unvented counterparts. This lighter taste provides concrete and ill founded reassurance to the Light smoker. Secondly, filter ventilation facilitates compensatory smoking by promoting the taking of bigger puffs. Thirdly, vent blocking appears to be a substantial problem on $1 \mathrm{mg}$ tar, heavily ventilated cigarettes, in addition to promoting still larger puffs. Filter ventilation is an ingenious device for an industry that acts to appease regulators and satisfy consumers. It directly reduces standard toxin yields, while at the same time it carries to human beings a false sense of security through the milder taste and continued risk through bigger puff volumes and behavioural vent blocking on the most heavily vented brands. Filter vents should be recognised as a deceptive and defective design feature and their use banned. Governments should take ventilation into account in regulatory structures, particular yield maximums. Health interested groups should test cigarettes in a way that reflects compensatory smoking. Lower tar (vented filter) cigarettes should be discouraged as a harm reduction product and actively counter-marketed.

\section{ACKNOWLEDGEMENTS}

Thanks go to Andrew Strasser for his comments on earlier drafts of this manuscript.

Authors' affiliations

L T Kozlowski, R J O'Connor, Department of Biobehavioral Health, The Pennsylvania State University, Pennsylvania, USA 


\section{REFERENCES}

1 Kozlowski LT, O'Connor RJ. Official cigarette tar tests are misleading: use a two-stage, compensating test. Lancet 2000;355:2159-61.

2 Hurt RD Robertson CR. Prying open the door to the tobacco industry's secrets about nicotine. JAMA 1998;280:1173-81.

3 Kozlowski LT, O'Connor RJ, Sweeney CT. Cigarette design. Risks associated with smoking cigarettes with low machine-measured yields of ar and nicotine. Smoking and Tobacco Control Monograph, 13. Bethesda, Maryland: National Cancer Institute, 2001.

4 Kozlowski LT, Mehta NY, Sweeney CT, et al. Filter ventilation and nicotine content of tobacco in cigarettes from Canada, the United Kingdom, and the United States. Tobacco Control 1998;7:369-75.

5 Jarvis M, Bates C. Why low tar cigarettes don't work and how the tobacco industry has fooled the smoking public. London: Action on Smoking and Health (www.ash.org.uk), 1999.

6 Creighton D. Compensatible filters. BAT; undated. www.hlth.gov.bc.ca/ guildford. Bates No. 100501670

7 BAT. Suggested Questions for CAC.III, August 26, 1977. BAT;1977. www.cdc.gov/tobacco (MN trial number 11,390)

8 BAT. Untitled. BAT; 1978. www.cdc.gov/tobacco (MN trial number $11,089)$

9 Pollay RW, Dewhirst T. Successful images and failed fact: the dark side of marketing seemingly Light cigarettes. History of Advertising Archives, Working Paper \#99.4. 1,2000:52p, plus exhibits

10 Peeler CE. Cigarette testing and the Federal Trade Commission: a historical overview. The FTC cigarette test method for determining tar, nicotine, and carbon monoxide yields of US cigarettes: report of the NCI Expert Committee. Bethesda, Maryland: National Institutes of Health, 1996. (NIH Publication No 96-4028.)

11 Bradford JA, Harlan WR, Hanmer HR. Nature of cigarette smoke. Technique of experimental smoking. Industrial and Engineering Chemistry 1936;28:836-9

12 Rodgman A. FTC "tar" and nicotine in cigarette mainstream smoke: retrospective. Recent Advances in Tobacco Science 1997;23:5-74.

13 Quit Victoria. Tar, nicotine, and carbon monoxide levels. Quit Victoria 1995. www. quit.org.au/Fandl/fandi/c05s3.htm

14 Action on Smoking and Health. Tar, nicotine and carbon monoxide yields of cigarettes. London: ASH UK, 1999. www.ash.org.uk/html/ regulation/html/tartables. html

15 Commission of the European Communities. Proposal for a directive of the European Parliament and of the council on the approximation of the laws, regulation and administrative provisions of the Member States concerning the manufacture, presentation and sale of tobacco products. COM(1999) 594 final; Brussels: 1999

16 Kozlowski LT. Smokers, non-smokers, and low-tar smoke [letter]. Lancet $1981 ; i(8218): 508$

17 Kozlowski LT, Sweeney CT. Low-yield, light, and ultra-light cigarettes: let's understand the product before we promote. In: Goldberg ME, Fishbein M, Middlestadt S, eds. Social marketing: theoretical and practical perspectives. New Jersey: Erlbaum, 1997.

18 Kozlowski LT. Perceiving the risks of low-yield ventilated-filter cigarettes: the problem of hole-blocking. In: Covello V, Flamm WG, Rodericks J, Tardiff R, eds. Proceedings of the International Workshop on the Analysis of Actual vs. Perceived Risksm. Plenum, 1983:175-82.

19 Browne CL. The design of cigarettes, 3rd ed: Hoechst Celanese, 1990.

20 Norman AB, Newsome JB, Reynolds JH. Effects of tipping perforation method and vent location on filter ventilation during smoking. R.J. Reynolds; 1984. www.rirtdocs.com Bates No. 504017981.

21 Morie GP, Baggett MS. Effect of filter ventilation on some physical and chemical properties of cigarette smoke. Tennessee Eastman Company [for RJ Reynolds]; undated. www.rirtdocs.com Bates No. 503877100

22 Philip Morris. Cigarettes a la carte - or - How to play with filter efficiency, filter dilution and expanded tobacco in designing low- and very-low-tar cigarettes. Philip Morris; 1980. www.pmdocs.com Bates No. 2501224987

23 Altizer CB, Bolanowski GJ, Christopher RW, et al. Ventilation seminar. Philip Morris; 1983. www.pmdocs.com Bates No. 2057251669.

24 Stolt $\mathbf{P}$. Update on program for the reduction of Marlboro smoke deliveries in Europe by means of filter dilution. Philip Morris; 1982. www.pmdocs.com Bates No. 2024270885.

25 Byrd GD, Robinson JH, Caldwell WS, et al. Comparison of measured and FTC-predicted nicotine uptake in smokers. Psychopharmacology 1995; 122:95-103

26 Byrd GD, Davis RA, Caldwell WS, et al. A further study of FTC yield and nicotine absorption in smokers. Psychopharmacology 1998;139:291-9.

27 Jarvis MJ, Boreham R, Primatesta $P$, et al. Nicotine yield from machine-smoked cigarettes and nicotine intakes in smokers: evidence from a representative population survey. J Natl Cancer Inst 2001;93:134-8

28 Burns D, Major J, Shanks T, et al. Smoking lower yield cigarettes and disease risk. In: Risks associated with smoking cigarettes with low machine-measured yields of tar and nicotine. Smoking and Tobacco Control Monograph, 13. Bethesda, Maryland: National Cancer Institute 2001

29 Royal College of Physicians. Nicotine addiction in Britain: a report of the Tobacco Advisory Committee of the Royal College of Physicians. London: Royal College of Physicians, 2000.

30 Kozlowski LT, Frecker RC, Khouw V, et al. The misuse of 'less-hazardous' cigarettes and its detection: hole-blocking of ventilated filters. Am J Public Health 1980;70: 1202-3.

31 Kozlowski LT, Rickert WS, Pope MA, et al. A color-matching technique for monitoring tar/nicotine yields to smokers. Am J Public Health 1982;72:597-9.
32 Kozlowski LT, Rickert WS, Pope MA, et al. Estimating the yield to smokers of tar, nicotine, and carbon monoxide from the 'lowest yield' ventilated filter-cigarettes. Br J Addict 1982;77:159-65.

33 Kozlowski LT, Pope MA, Lux JE. Prevalence of the misuse of ultra-low-ta cigarettes by blocking filter vents. Am J Public Health 1988;78:694-5.

34 Kozlowski LT, Pillitteri JL, Sweeney CT. Misuse of "light" cigarettes by means of vent blocking. J Subst Abuse 1994:6:333-6.

35 Sweeney CT, Kozlowski LT, Parsa P. Effect of filter vent blocking on carbon monoxide exposure from selected lower tar cigarette brands. Pharmacol Biochem Behav 1999;63:167-73.

36 Sweeney CT, Kozlowski LT. Blocking filter vents increases carbon monoxide levels from ultralight, but not light cigarettes. Pharmacol Biochem Behav 1998:59:767-73.

37 Kozlowski LT, Goldberg ME, Sweeney CT, et al. Smoker reactions to a radio message' that light cigarettes are as dangerous as regular cigarettes. Nicotine and Tobacco Research 1999;1:67-76.

38 Kozlowski LT, Goldberg ME, Yost BA. Measuring smokers' perceptions of the health risks from smoking light cigarettes [letter]. Am J Public Health 2000;90:1318-9.

39 Kozlowski LT, Goldberg ME, Yost BA, et al. Smokers' misperceptions of light and ultra-light cigarettes may keep them smoking. Am J Prev Med 1998;15:9-16.

40 Kozlowski LT, Goldberg ME, Yost BA, et al. Smokers are unaware of the filter vents now on most cigarettes: results of a national survey. Tobacco Control 1996;5:265-70

41 Kozlowski LT, White EL, Sweeney CT, et al. Few smokers know their cigarettes have filter vents [letter]. Am J Public Health 1998;88:681-2.

42 Ferris RP. The phenomenon of Lights. BAT; undated. www.hlth.gov.bc.ca/guildford Bates No. 403683466

43 Goldstein Krall Marketing Resources. Brand extension for Marlboro. Philip Morris; 1979. www.pmdocs.com Bates No. 2045783341

44 Crellin RA. The role of behavioural studies in ultra low tar product development. BAT; 1994. www.cdc.gov/tobacco Bates No. 403682327

45 Irwin D. Ultra Low tar smokers - What do they seek from their brands? Are they getting it? BAT; 1994. www.cdc.gov/tobacco Bates No. 403683414

46 Philip Morris. Key facts about the Ultra Light business. Philip Morris undated. www. pmdocs.com Bates No. 2043901768

47 Kwechansky Marketing Research. Project Plus/Minus. Imperial Tobacco; 1982. www.cdc.gov/tobacco Bates No. 566627751

48 Kozlowski LT, Appel CP, Frecker RC, Khouw W. Nicotine, a prescribable drug available without prescription [letter]. Lancet 1982;i(8267):334.

49 Leahy RJ. Ventilated cigarettes. Philip Morris; 1955. www.pmdocs.com Bates No. 1001900716

50 Gray RJ. Preliminary report - ventilated cigarettes in blind test and with copy clinics. Philip Morris; 1959. www.pmdocs.com Bates No. 1000323708.

51 Kozlowski LT. Some lessons from the history of American tobacco advertising and its regulations in the 20th century. In: Ferrence R, Slade J, Room R, Pope M, eds. Nicotine and public health. Washington DC: American Public Health Association, 2000:17-35.

52 Patterson JT. The dread disease: cancer and modern American culture. Cambridge, Massachusetts: Harvard University Press, 1989.

53 DuPuis RH. 'Confidential' memo. Philip Morris; 1956. www.pmdocs.com Bates No. 1001809856

54 Philip Morris. Do you think a cigarette is only this? Philip Morris; 1960 www.pmdocs.com Bates No. 1000323714

55 Danker RH. Ventilation studies. Philip Morris; 1959. www.pmdocs.com Bates No. 1001900768

56 Thun MJ, Day-Lally CA, Calle EE, et al. Excess mortality among cigarette smokers: changes in a 20-year interval. Am J Public Health 1995;85:1223-30.

57 Thun MJ, Lally CA, Flannery JT, et al. Cigarette smoking and changes in the histopathology of lung cancer. J Natl Cancer Inst 1997;89:1580-6.

58 Anderson P. HTI test of production Marlboro 85 versus Marlboro 85, Model " 1 " with $10 \%$ dilution and no reduction in tar delivery. Philip Morris; 1979. www.pmdocs.com Bates No. 2040077052.

59 Hirii T. Effects of paper permeability, filtration, and tip ventilation on deliveries, impact, and irritation. BAT;1980. www.bw.aalatg.com Bates No. 650331009

60 Philip Morris. Korea product tests. Philip Morris; 1989 www.pmdocs.com Bates No. 2504034439

61 Kozlowski LT, Sweeney CT, Pillitteri JL. Blocking cigarette filter vents with lips more than doubles carbon monoxide intake from ultra-low tar cigarettes. Exp Clin Psychopharmacol 1996;4:404-8.

62 Baker RR, Lewis LS. Filter ventilation - has there been a 'cover-up'? Recent Advances in Tobacco Science 1997;23:152-96.

63 Zacny JP, Stitzer ML, Yingling JE. Cigarette filter vent blocking: Effects on smoking topography and carbon monoxide exposure. Pharmacol Biochem Behav 1986;25:1245-52

64 FTC vs. Brown \& Williamson Tobacco Corporation: 580.SUPP 981 (D.C.C., 1983), 778F.2d 35 (D.C.CIR. 1985), 1985.

65 Brown \& Williamson. Barclay - Consumer perceptions (advertising and filter awareness. Brown \& Williamson; 1990. www.cdc.gov/tobacco Bates No. 604003895

66 BAT. Barclay. BAT; undated. www.cdc.gov/tobacco Bates No. 604003869

67 Filter Products Research Laboratory. The effect of ventilation on cigarette taste at constant pressure drop and constant tar delivery. Eastman Kodak Company [for Brown \& Williamson]; 1988. www.bw.aalatg.com Bates No. 575105255. 
68 Martin P. The influence of tipping paper color on strength and preference. Philip Morris; 1977. www.pmdocs.com Bates No. 1003367524

69 McCarthy RF. Re: Harshness workshop. R.J. Reynolds;1985. www.rirtdocs.com Bates No. 504650374.

70 Dunn WL. Nicotine and inhalation impact. Philip Morris; 1973. www.pmdocs.com Bates No. 1003295309.

71 Drummond-Dunn D. Italy - Strength/Lightness perception study December 1990. Philip Morris; 1991. www.pmdocs.com Bates No. 2501151288

72 Horsewell HG. Project Tiffin. BAT; undated. http://www.cdc.gov/ tobacco Bates No. 105341345

73 Crayton FH. Effects of ammonia - odor and smoke. Philip Morris; 1971. www.cdc.gov/tobacco Bates No. 2047348041

74 Kelley MF. Smoker response evaluation of Macho I, II, and III versus Marlboro 85 and Merit 85. Philip Morris; 1980. www.pmdocs.com Bates No. 2023779500

75 Long LL. Summary of results on ventilated cigarettes. Philip Morris;1955. www.pmdocs.com Bates No. 1001900842.

76 Goodman B. Marlboro - Marlboro lights study delivery data. Philip Morris; 1975. www.pmdocs.com Bates No. 2021544486

77 Goodman BL. Summary of human smoker simulator program. Philip Morris; 1977. www.pmdocs.com Bates No. 1003728025.

78 Creighton D. McGillivray LM. The effect of changed deliveries at constant pressure drop on human smoking pattern. BAT; 1971. www.hlth.gov.bc.ca/guildford Bates No. 10293968.

79 Creighton DE, Watts RM. The effect of introducing pinholes in front of the filter on human smoking pattern. BAT; 1972. www.cdc.gov/tobacco Bates No. 650316736

80 Mendell S. The relationship between dilution/RTD ratios and consumer perception. Philip Morris; 1983. www.pmdocs.com Bates No. 1003638145

81 Goodman B. The influence of dilution on smoker parameters. Philip Morris; 1975. www.pmdocs.com Bates No. 2023779234

82 Goodman BL. Changes in smoker profiles with changes in nicotine and tar deliveries, both on and off smoking profile recorders. Philip Morris; 1977. www.pmdocs.com Bates No. 1000364678.

83 Sutton SR, Feyerabend C, Cole PV, et al. Adjustment of smokers to dilution of tobacco smoke by ventilated cigarette holders. Clin Pharmacol Ther 1978;24:395-405.

84 Hirii T. High taste to tar ratio products summary. BAT; 1984. www.cdc.gov/tobacco Bates No. 102393928

85 Kozlowski LT. The determinants of tobacco use: cigarette smoking in the context of other forms of tobacco use. Can J Public Health 1982;73:236-41.

86 Martin J, Dunn WL. A study of the effect of air hole blockage on gross puff volume in air diluted cigarettes. Philip Morris; 1967. www.pmdocs.com Bates No. 1001892505

87 Osmalov JS. Cigarettes used in study of lip occlusion over dilution holes. Philip Morris; 1967. www.pmdocs.com Bates No. 1001891441

88 Philip Morris. X6D7AKP (Merit-type cigarette). Standard smoking vs. human smoker simulator [Free-standing table]. Philip Morris;1978. www.pmdocs.com Bates No. 2001244817.

89 Herning RI, Jones RT, Bachman J, et al. Pull volume increases when low-nicotine cigarettes are smoked. BM 1981;283:187-9.

90 Diordjevic MV, Hoffman D, Hoffman I. Nicotine regulates smoking patterns. Prev Med 1997; 26:435-40.

91 Diordjevic MV, Stellman SD, Zang E. Doses of nicotine and lung carcinogens delivered to cigarette smokers. J Ntl Cancer Inst 2000;92:106-11.

92 Morgan WT, Villegas EH, Davis CC, et al. NPT menthol human smoking behavior basic learning study. R.J. Reynolds; 1990. www.rirtdocs.com Bates No. 508025123

93 Norman V, Ihrig AM. The concept of a power function to describe smoking effort. Lorillard; 1980. www.lorillarddocs.com Bates No. 00303446.

94 Norman V, Ihrig AM. A study of human smoking patterns of ultra-low yield cigarettes. Lorillard; 1980. www.lorillarddocs.com Bates No. 00782382

95 Norman V, Ihrig AM. Effort required to obtain extra smoke from various cigarette brands. Lorillard; 1981. www.lorillarddocs.com Bates No. 00268273

96 Norman V. Estimation of the amount of smoke obtained by human smokers from different cigarette brands. Lorillard;1981. www.lorillarddocs.com Bates No. 00400830.

97 Zalis MJ. Cigarette smoking machine puff volume vs. actual smoker volume. Philip Morris; 1970. www.pmdocs.com Bates No. 1000837497

98 Dixon $M$. Derrick M. The monitoring of puffing and inhaling patterns of consumers of middle and low tar delivery cigarettes. BAT;1986. www.cdc.gov/tobacco Bates No. 400746159.

99 R.J. Reynolds. Influences of cigarette design on human puffing patterns. R.J. Reynolds; undated. www.rirtdocs.com Bates No. 504368245.

100 R.J. Reynolds. The design of cigarettes: IX. Human smoking parameters. R.J. Reynolds;undated. www.rirtdocs.com Bates No. 505440554

101 Stowe ME. Smoke delivery of some ultra-low tar cigarettes at increased puff volumes. R.J. Reynolds Tobacco Company. R.J. Reynolds; 1979. www.rirtdocs.com Bates No. 512325229.

102 Townsend DE. The effects of puff parameters and air dilution level on tar and nicotine delivery: Now 85 and Barclay 85. R.J. Reynolds; 1982 www.rirtdocs.com Bates No. 510934863.

103 Kelley MF. Average Merit 85 smoker parameters and deliveries vs. standard smoker procedure. Philip Morris; 1979. www.pmdocs.com Bates No. 2023779388.
104 RJ Reynolds. Air dilution and factors that affect it. RJ Reynolds; undated. Available at www.rirtdocs.com Bates No. 503144833

105 Genoud Y, Zwahlen A. Effect of puff volume variations on DPM and nicotine deliveries of Prototype 84P and Philip Morris ultra light. Philip Morris; 1987. www.pmdocs.com Bates No. 2028629469.

106 Dunn WL, Jones JA. Behavioral Research - 1600 Behavioral Research Laboratory Annual Report Part II. Philip Morris; 1982. www.pmdocs.com Bates No. 1003179010

107 Kelley MF. Evaluation of a PM 2 mg experimental cigarette versus Now and Carlton 70. Philip Morris; 1977. www.pmdocs.com Bates No. 1000364294.

108 Creighton D. Smoking behaviour (low delivery cigarettes). BAT; 1977 www.cdc.gov/tobacco Bates No. 105456335.

109 Wakeham H. Some unexpected observations on tar and nicotine and smoker behavior. Philip Morris; 1974. www.pmdocs.com Bates No. 1000260471.

110 Casey WJ. Data related to very high air dilution cigarettes. R.J. Reynolds; 1994. www.rirtdocs.com. Bates No. 512480043

111 Norman V. Variation of tip dilution with puff flow rate. Lorillard; 1982 www.lorillarddocs.com Bates No. 00687042.

112 Creighton DE. Measurement of the degree of ventilation of cigarettes at various flow rates. BAT; 1978. www.cdc.gov/tobacco Bates No. 105586447.

113 Anon. Puff volume and duration effects on deliveries of ultra low tar cigarettes. Brown and Williamson; 1981.www.bw.aalatg.com/ public.htm Bates No. 620503792.

114 Kozlowski LT. Blocking the filter vents of cigarettes [letter]. JAMA 1986;256:3214.

115 Pillitteri JL, Morse AC, Kozlowski LT. Detection of vent-blocking on light and ultralight cigarettes. Pharmacol Biochem Behav 1994;48:539-42.

116 Porter A, Dunn P. Mouth insertion depths in Canadian smokers. Beitrage zur Tabakforschung International 1998;18:85-91.

117 Baker RR, Dixon M, Hill CA. The incidence and consequences of filter vent blocking amongst British smokers. Beitrage zur Tabakforschung International 1998; 18:71-84.

118 Rickert WS, Robinson JC, Young JC, et al. A comparison of the yields of tar, nicotine, and carbon monoxide of 36 brands of Canadian cigarettes tested under three conditions. Prev Med 1983;12:682-94.

119 Hirii T. Simulation of the effect of human smoker blocking the tip ventilation on Cambridge. BAT;1982. www.hlth.gov.bc.ca/guildford Bates No. 401089371

120 Ihrig AM. By-pass filter for low tar cigarettes. Lorillard; 1977. www.lorillarddocs.com Bates No. 00384559.

121 Schultz FJ. By pass filter. Lorillard; 1977. www.lorillarddocs.com Bates No. 00384558 .

122 Wickham JE. Reduction of smoke constituents by dilution of Parliament 100's. Philip Morris, 1968. www.pmdocs.com Bates No. 2051632120.

123 Nepamuceno JG, Houck WG. The effects of ventilation hole blocking on cigarette delivery. Philip Morris Incorporated; 1982. www.pmdocs.com Bates No. 202250250.

124 Goodman B. Effect of reduced dilution on tar delivery to a smoker. Philip Morris Incorporated; 1982. www.pmdocs.com Bates No. 1003415278.

125 Dunn WL. A study of the effect of lip occlusion of air holes on main stream delivery in air diluted cigarettes. Philip Morris; 1967. www.pmdocs.com Bates No. 1001892531

126 Philip Morris. Mouth placement study. Philip Morris; undated. www.pmdocs.com Bates No. 2046816482

127 Sweeney CT. Experimental research on the behavioral blocking of filter vents on low yield cigarettes [doctoral dissertation]. Pennsylvania State University, 1998.

128 Helms A. The concentration of tar, nicotine and carbonmonoxid in the smoke of ventilated filter cigarettes - comparison of different types of filte ventilation. Hauni-Werke Kurbar \& Co; 1983. www.pmdocs.com Bates No. 2028562439.

129 Helms A. Influence of laser perforation of cigarette filters on the smoke composition: influence of the depth of the holes. Hauni-Werke Kurbar \& Co; 1984. www.pmdocs.com Bates No. 2028562407

130 BAT Suisse. Insertion depth study on Swiss cigarettes. BAT Suisse; 1984 www.pmdocs.com Bates No. 2501268539.

131 McBride C. A study to determine the maximum cigarette insertion depth used by Canadian smokers [abstract]. Imperial Tobacco; 1985. www.tobaccopapers.org Bates No. 109874617.

132 Kozlowski LT. Less hazardous smoking and the pursuit of satisfaction [editorial]. Am J Public Health 1987:77:539-41.

133 Kozlowski LT, Yost B. Stine MM, Celebucki C. Massachusetts advertising against light cigarettes appears to change beliefs and behavior. Am J Prev Med 2000; 18:339-42.

134 Giovino GA, Tomar SL, Reddy MN, et al. Attitudes, knowledge, and beliefs about low-yield cigarettes among adolescents and adults. The FTC cigarette test method for determining tar, nicotine, and carbon monoxide yields of US cigarettes: report of the NCl Expert Committee. Bethesda, Maryland: National Institutes of Health, 1996. (NIH Publication No 96-4028.)

135 Kozlowski LT, Heatherton TF, Frecker RC, Nolte HE. Self-selected blocking on vents on low-yield cigarettes. Pharmacol Biochem Behav 1989;33:815-9.

136 Philip Morris. Carlton and Now smokers. Philip Morris; undated www.pmdocs.com Bates No. 2043901983

137 Oldman M. Understanding the smoking process - The way forward for low delivery products. BAT; 1982. www.cdc.gov/tobacco Bates No. 100163662 
138 E.J. Wolf and Associates. An exploratory study of consumer perceptions of and attitudes toward "light" cigarettes. R.J. Reynolds; 1978. www.rirtdocs.com Bates No. 500316535

139 BAT. R\&D/Marketing conference - New brand development - "post lights." BAT;undated. www.cdc.gov/tobacco Bates No. 100501581

140 Slade J. Innovative nicotine delivery devices from tobacco companies. In: Ferrence R, Slade J, Room R, Pope M, eds. Nicotine and public health. Washington DC: American Public Health Association, 2000.

141 Shopland D. Cigars, pipes, and other traditional tobacco products. In: Ferrence R, Slade J, Room R, Pope M, eds. Nicotine and public health. Washington, D.C.: American Public Health Association, 2000.

142 Ramstrom LM. Snuff-An alternative nicotine delivery system. In: Ferrence R, Slade J, Room R, Pope M, eds. Nicotine and public health. Washington, D.C.: American Public Health Association, 2000.

143 Kozlowski LT. Less-hazardous tobacco use as a treatment for the "Smoking and Health" problem. In: Smart, Cappell, Glaser, et al, eds. Research advances in alcohol and drug problems. Plenum Publishing Corp, 1984
144 Leistikow BN, Martin DC, Milano CE. Fire injuries, disasters, and costs from cigarettes and cigarette lights: a global overview. Prev Med 2000;31:91-9

145 California Environmental Protection Agency. Health effects of exposure to environmental tobacco smoke: Smoking and Tobacco Control Monograph 10. Bethesda, Maryland: National Cancer Institute, 1999.

146 Massachusetts Department of Public Health. CMR 665.000: Testing and reporting of constituents of cigarette smoke. http:// www.state.ma.us/dph/mtcp/report/smoktox.htm, 2000

147 Tobacco Free Initiative. Final report: advancing knowledge on regulating tobacco products. Geneva: World Health Organization; 2000.

148 Gori GB, ed. Toward less hazardous cigarettes - the third set of experimental cigarettes. Washington DC: US Department of Health, Education, and Welfare, 1977

149 Kozlowski LT, Strasser AA, Giovino GA et al. Applying the risk/use equilibrium: use medicinal nicotine now for harm reduction. Tobacco Control $2001 ; 10: 201-3$.

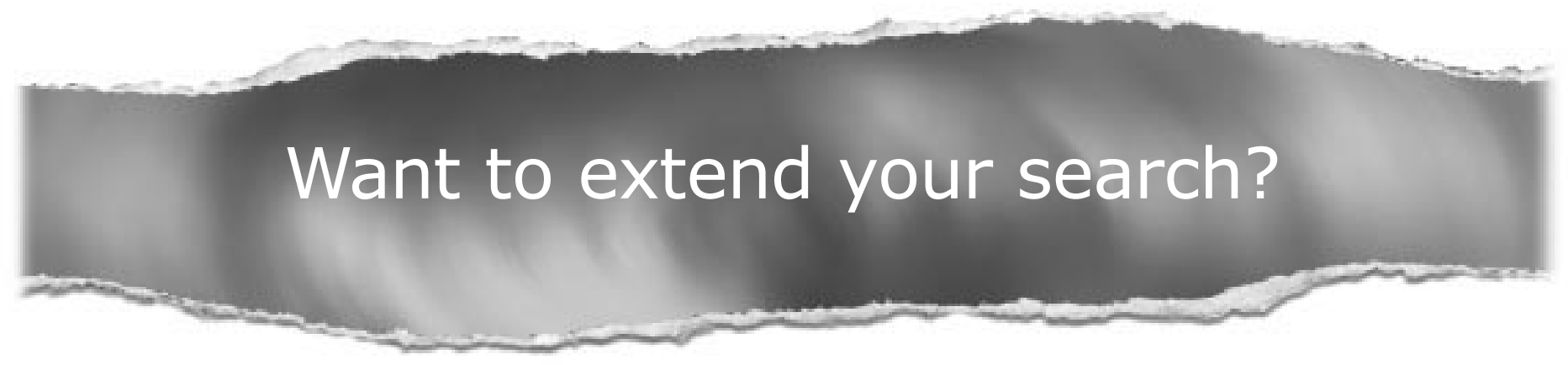

\section{Cross journal searching}

If you can't find what you are looking for in Tobacco Control you can extend your search across many of the more than 200 journals available for selection. You can restrict your search to specific subject areas

(eg, clinical medicine, basic research), or select specific journals, or search all available titles.

www.tobaccocontrol.com 